\title{
Economic Valuation of the Goods and Services Offered by the High Relict High-Andean Ecosystem Located in the Districts of Chiguata, Characato and Pocsi, Arequipa, Peru
}

\author{
Jacques Araca ${ }^{1 *}$, Vicent Estruch-Guitart ${ }^{2}$, Jerónimo Aznar², Sonia Yufra ${ }^{1}$ \\ ${ }^{1}$ Universidad Nacional de San Agustín de Arequipa, Peru \\ ${ }^{2}$ School of Agricultural and Environmental Engineering, Department of Economics and Social Sciences, \\ Universitat Politècnica de Valéncia, Spain
}

Received: 10 November 2020

Accepted: 15 May 2021

\begin{abstract}
The relict high-Andean forest covered by associations of Polylepis Rugulosa found in the arid Andean region of southwestern Peru is a provider of a series of environmental goods and services such as water supply, climate regulation, erosion control, among others, that contribute to the wellbeing of societies. This investigation allows us to know the allocation of a range of economic value of the ecosystem services developed in the study area, based on different perspectives of analysis through the application of the multicriteria model Analytic Network Process (ANP) and the economic estimation of $\mathrm{CO}_{2}$ eq sequestration. The results obtained range from USD 32,641,387 to USD 102,098,052.
\end{abstract}

Keywords: AMUVAM, ANP, ecosystem goods and services, economic valuation

\section{Introduction}

Ecosystem goods and services represent the basis of socioeconomic activities for the promotion of social welfare, through the direct and indirect benefits obtained by the development of ecosystem processes [1-2]. The most accepted classification by the scientific community, elaborated in the Millennium Ecosystem Assessment (MA), was proposed in 2005 [3], whose matrix divides ecosystem services into 4 functional lines: (1) provisioning services, like those provided

*e-mail: jaraca@unsa.edu.pe directly by the ecosystem to society, generally with some economic benefit; (2) regulating services, those benefits obtained from the ecological processes that maintain the health of ecosystems and allow life to develop; (3) supportive or supporting services, such as the processes necessary for the generation of the other ecosystem services; (4) cultural services, such as the non-material benefits obtained from natural ecosystems, which support the sustainment of human life by providing opportunities for health, spiritual growth, cognitive development, recreation, cultural identity, and aesthetic experiences [4].

The forests are ecosystems known for being areas largely covered by tree communities, which are interrelated with the socioeconomic component 
through ecosystem goods and services. Today, this interrelationship brings about development opportunities for about 1.6 billion people in the world [5]. However, over the last 30 years, forests have lost 178 million hectares, owing to the inadequate development of commercial and subsistence agriculture, infrastructure, urban expansion and mining activity [6-7]. Peru has 73.3 million hectares of forests, of which 69.2 million are in the jungle region, 3.2 million in the coast and 0.89 million in the highlands [8]; the latter are considered Andean forests, which, like the Amazonian and coastal forests, provide high value goods and services, among the most relevant are the following: the provision of fuels through the extraction of woody material; carbon sequestration allowing the creation of the climate regulation service; the biomass of plant organisms, which help reduce erosion rates and prevent mass movement; the landscape and aesthetic values, which allow the development of economic and cultural activities.

Peru's Andean forests have been the topic of study in more than 510 articles published in different journals; however, only $0.98 \%$ have studied the goods and services provided by these ecosystems, evidencing the lack of this type of evaluation [9].

The relict high-Andean forest that is studied in this article represents $0.12 \%$ of the Peruvian territory and its extension is largely covered by arboreal associations of Polylepis spp, characterized by being fragile, with a complex floristic diversity and endemisms, consequences of difficult topography and accessibility [10]. Unfortunately, it is currently known that its degradation is being generated [11], some studies indicate that its current condition corresponds to just $10 \%$ of what was once its initial extent [12].

The withdrawal of forest ecosystems has attracted the interest of the scientific community, studying different strategies for the use and management of these ecosystems; thus, among the most developed studies is environmental economic valuation, which is defined as the "tool used to quantify, in monetary terms, the value of ecosystem goods and services" [13], the usefulness of these studies lies in the importance of the information regarding the improvement of different governmental decisions, such as: regulations, budgets, subsidies, investments, compensation mechanisms, tax burdens, among others [14].

Although there is a small group of environmental goods and services that have direct economic transaction markets, most of them do not have this characteristic because they are for public consumption and do not present rivalry or exclusivity [15], for this reason, traditional methods of economic valuation focus their analysis on the creation of artificial markets (contingent valuation method) or on the indirect projection on real markets (avoided cost method, travel cost and hedonic prices), however, for some economists and environmentalists the results are still disputed [16]; despite the fact that the existence of a market allows for a more reliable estimate, the biases of the methods allow for overestimates, underestimates or even incomplete appraisals.

For this study, the analytical method of multicriteria valuation (AMUVAM) has been selected as an alternative method, owing to: (1) the ability to analyze all the goods and services offered by the ecosystem; (2) the possibility of determining an economic value interval; and (3) the consistency of the results [17]; (4) inclusion of qualitative values and different perspectives [18]; (5) adaptation to any type of economic and territorial environment [19].

In the study we propose to estimate an interval of the economic value of the ecosystem goods and services offered by the relict high-Andean forest of Polylepis Rugulosa, part of the buffer zone of the National Reserve of Salinas and Aguada Blanca in the east-southeast of the city of Arequipa, Peru; we will begin with a brief description of the study area, and then identify the ecosystem goods and services based on a first phase of interviews, then we will develop the weighting of the identified components through a second phase of interviews and with the support of Super Decisions software we will process the data, the results will be first evaluated by the cluster analysis tool in the SPSS software to identify the different perspectives of the evaluators, then the economic value of a known good or service will be assessed for its subsequent projection and determination of the total economic value of the goods and services offered by the ecosystem. The results will have the potential to support local management for an adequate decision making associated to the use, exploitation and conservation of the forest.

\section{Materials and Methods}

\section{Study Area}

The study area corresponds to the Relict highAndean Forest of the arid Andean region of southwestern Peru, characterized by associations of Polylepis Rugulosa, locally known as "Queñoal", with an area of 4,007.91 hectares, high fragmentation and poor accessibility. This area is located in the buffer zone of the Salinas y Aguada Blanca National Reserve in the districts of Chiguata, Characato and Pocsi in the province and region of Arequipa. In geomorphological terms, it is a plateau with volcanic structures that are part of the Andean volcanic mountain range, with soils characteristic of the Altiplano steppe [20].

The species of Polylepis rugulosa presents a restricted distribution to dry puna habitats, with limited rainfall and slow growth that does not exceed $5 \mathrm{~m}$ in height [21]. Other species of flora and fauna representative of the region are also found within the area [22]. 


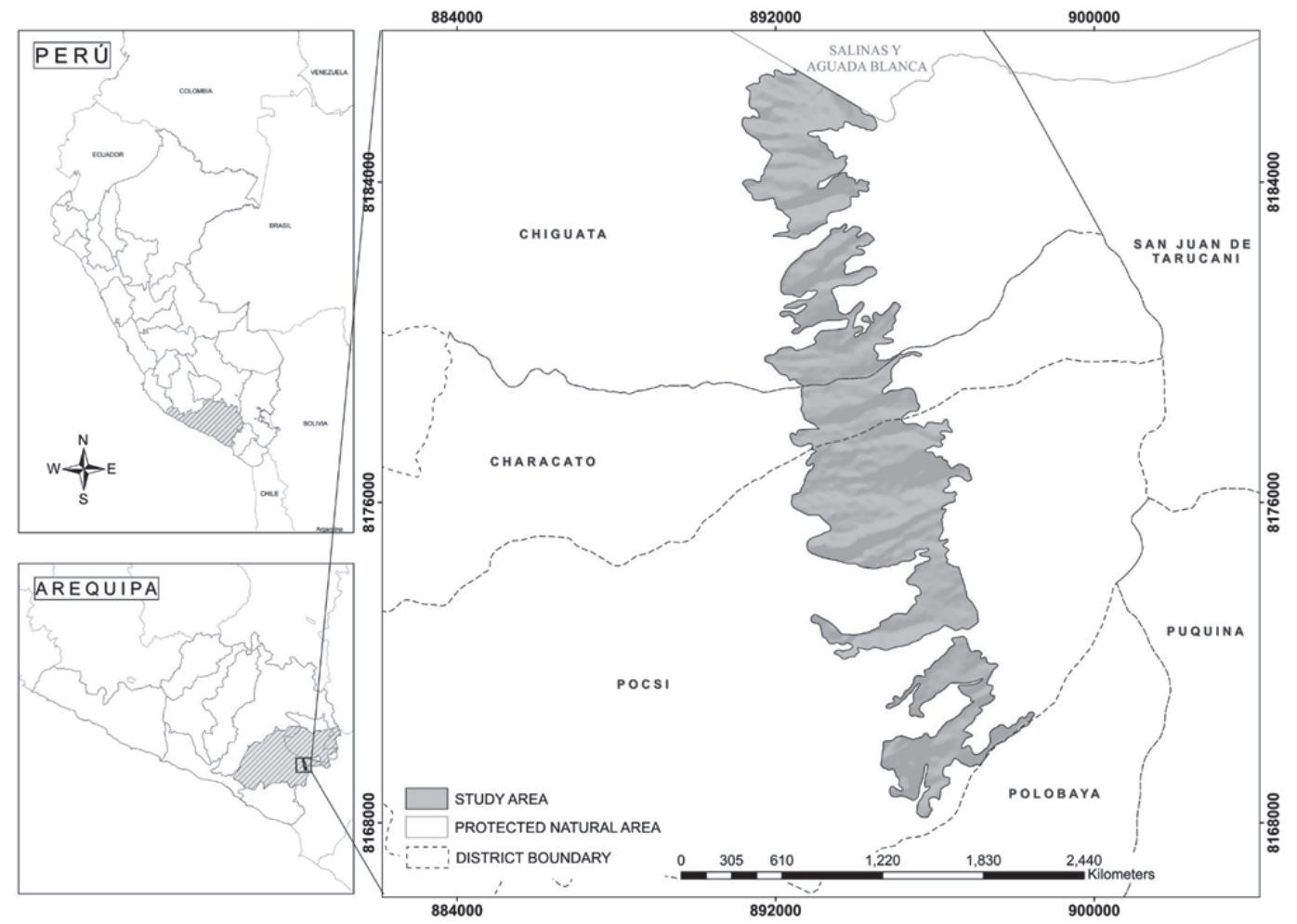

Fig. 1. Geographic location of the study area.

\section{Analytic Multicriteria Valuation Method (AMUVAM)}

The modified AMUVAM method is used to estimate the economic value of the ecosystem services provided by the study area; its basic structure includes the application of the Analytical Hierarchical Process (AHP) and the rent updating method. The modification is based on the replacement of the AHP model by the Analytical Network Process (ANP) proposed in 2004 by Professor Thomas L. Saaty [23], this represents a generalization of the previous one, both of them have the same purpose, obtaining a weighting for each component or ecosystem service in this case, however, there are some limitations in the AHP model because it does not study the interdependence and feedback relationships between the elements of the system, presenting the ANP model as the one that can analyze these relationships, but at the same time becoming more complex [24].

While the method of updating rents allows the monetary quantification of goods or services that present direct markets, generally provisioning services show this characteristic, the problem arises when the ecosystem does not provide this type of service. In this context, the present study works with the climate regulation service, based on the valuation of the ecosystemic process of carbon sequestration in its different reserves. The economic value obtained is used as a pivot for estimating the goods and services offered by the ecosystem.

\section{Selection of Experts}

In total, 9 experts with experience in the study area with reforestation projects, environmental economic valuation, ecosystem services, and forest management, among others, were selected. These are academics and researchers from the university, professionals working in specialized public technical agencies of the Peruvian government and representatives of the communities adjacent to the study area.

\section{Identification of Ecosystem Services}

The identification of ecosystem goods and services is especially important in environmental economic valuation because this process can lead to overestimation or double counting of economic value [25], for this reason, some considerations were established as follows: (1) referring to supporting ecosystem services as a classification in terms of economic valuation is a common mistake in this type of study, since they are evaluated as part of the process of developing the final ecosystem services, which ultimately are the only ones perceived by the society [26-27]; (2) identifying potential and realized ecosystem services, the former being the services provided by the ecosystem as a whole and the latter as those that are actually used by society [28]; (3) take into consideration that ecosystem services have a degree of importance for society according to their location and geographic context [29]. 
Based on the classification proposed by the Millennium Ecosystem Assessment (MA) [3], eight experts were surveyed who analyzed each good and service offered by the ecosystem, classifying them as of "high importance", "moderate importance", "low importance", "non-existent" or "unknown"; subsequently a frequency analysis was performed with the data obtained, accepting the services that are labeled as "high importance" for at least four experts and discarding the others, because they do not reflect representativeness of the forest [30].

\section{Calculation of Prioritization Vectors}

Once the elements, goods and ecosystem services are known, their interdependencies and feedbacks are evaluated under the influence analysis in the process, the agents, the temporality and the effects that can be generated directly and indirectly among them; subsequently, this information is taken to the Super Decisions software version 2.8.0, where the ANP model is developed, finally obtaining the prioritization vectors of the ecosystem goods and services.

\section{Cluster Analysis}

The analysis of clusters by variables is developed using SPSS Statistics software version 25.0, this process allows us to evaluate the perceptions of the experts, segregating the prioritization vectors into groups according to their similarity.

\section{Obtaining the Economic Value of $\mathrm{CO}_{2}$ eq Sequestration}

At the beginning of the study, the study area does not present ecosystem services that have any direct use value, according to Aznar and Estruch [31] in 2015, indicate that it is possible to consider indirect use values, in this case determining the economic value of $\mathrm{CO}_{2}$ - eq sequestration allows us to establish the pivot to value the goods and services offered by the ecosystem as a whole.

The calculation of the carbon stock is based on the project developed by Sarcca [32] in 2017. This research was carried out in the same study area taken with a total of 4007.91 ha corresponding to the forest of Polylepis Rugulosa located in the districts of Pocsi, Characato and Chiguata in the city of Arequipa; the carbon stocks of different zones were evaluated, such as the arboreal aerial biomass corresponding to the woody part of the tree; the non-arboreal aerial biomass of herbs and shrubs corresponding to the understory and pre-existing vegetation; the subway biomass referring to the roots, detritus and litter that correspond to all plant material from the aerial part deposited in the soil; and finally the soil. The area was stratified according to the density of tree vegetation divided by strata using satellite images, obtaining strata with a low tree density of 1020.03 ha. (stratum 1), medium with 881.63 ha. (stratum 2) and high with 2103.24 ha. (stratum 3). The calculation of the biomass for each reserve was carried out. The aerial tree biomass was determined by constructing the allometric equation using dasometric data such as total height and crown diameter and then applying the extraction of individuals, separating them into branches, trunks and leaves, in addition to recording the weight data according to the manual proposed by Picard et al. [33] in 2012; likewise, the direct non-destructive method based on the allometric equation presented by Cairns et al. [34] was used to calculate belowground biomass in 1997; on the other hand, the herbaceous aerial biomass, the shrub aerial biomass and the biomass in litter and debris are determined by the destructive method; finally, the biomass in the soil is estimated by the wet oxidation method. In order to obtain the carbon density $(\mathrm{tnC} \mathrm{ha-1)}$ of each zone, the carbon-biomass ratio is displayed, from this data the carbon stock $(\operatorname{tnC})$ is calculated by multiplying by the stratum extension.

The values of the carbon stock stored in the reserves are used to calculate the $\mathrm{CO}_{2}$ - eq sequestered by

Table 1. Carbon Stock Data and $\mathrm{CO}_{2}$ eq.

\begin{tabular}{|c|c|c|c|c|c|}
\hline \multirow{2}{*}{ Reserve of carbon } & \multicolumn{3}{|c|}{ Stock of Carbon (t C) } & \multirow{2}{*}{ Total (t C) } & \multirow{2}{*}{ CO $_{2}$ eq (t) } \\
\cline { 2 - 5 } & Stratum 1 & Stratum 2 & Stratum 3 & 21026.66 & 77167.83 \\
\hline Arboreal & 2616.68 & 2468.24 & 15941.74 & 2353.54 & 8637.49 \\
\hline Bush & 316.41 & 443.16 & 1593.97 & 5722.43 & 21001.33 \\
\hline Herbaceous & 186.07 & 334.51 & 5201.85 & 5877.36 & 21569.90 \\
\hline Underground & 774.03 & 725.73 & 4377.60 & 5282.93 & 19388.33 \\
\hline Litter and debris & 721.73 & 936.35 & 3624.85 & 100222.23 & 367815.57 \\
\hline Floor & 21822.82 & 19581.66 & 58817.75 & 140485.14 & 515580.46 \\
\hline Total & 26437.74 & 24489.65 & 89557.75 & & \\
\hline
\end{tabular}

Source: Sarcca 2017. 
multiplying by the factor 3.67 which is the ratio between the molecular weights $\mathrm{CO}_{2} / \mathrm{C}$.

Table 1 shows the estimate of carbon stock by stratum and stock ( $\mathrm{t} \mathrm{C}$ ), and the calculation of the sequestration $\mathrm{tnCO}_{2}$ - eq in Bosque de Polylepis Rugulosa.

To obtain the economic value of $\mathrm{CO}_{2}$ eq, the social price of carbon developed by the Research Center of the Universidad del Pacífico using the Nordhaus methodology is used [35] accredited by the Ministry of Economy and Finance of the Peruvian government, this amounts to USD 7,17 $\mathrm{CO}_{2}$ eq $\mathrm{t}^{-1}$.

\section{Results and Discussion}

After the first phase of interviews and based on the projected importance to social welfare, the ecosystem goods and services offered by the relict highAndean forest were identified, highlighting that the following guidelines were taken into consideration: (1) participation of support services and their inclusion in the analysis [26-27]; (2) identification of the services actually developed [28]; (3) geographic predominance [29]. The first one is usually a common mistake in the bibliography, for this reason we present below an example applied to the study: the erosion control service is considered a support service that is based on controlling slow but constant erosion processes that act against soil formation processes, however, it is also considered a final regulation service, since this process avoids large movements of material that can have a direct impact on the settlements that are located below the study area bringing consequences in their welfare, in conclusion the evaluation of this service involves an analysis as a whole, since it is considered an intermediate service to be considered a final service.
Table 2. Identification of ecosystem processes and services

\begin{tabular}{|c|c|}
\hline \multicolumn{2}{|c|}{ Existing ecosystem services } \\
\hline $\begin{array}{l}\text { Provisioning } \\
\text { services (SA) }\end{array}$ & Water supply (PA) \\
\hline \multirow{5}{*}{$\begin{array}{l}\text { Regulatory serv- } \\
\text { ices (SR) }\end{array}$} & Air quality regulation (RCA) \\
\hline & Climate regulation $(\mathrm{RC})$ \\
\hline & Water regulation (RA) \\
\hline & Erosion control (CE) \\
\hline & Regulation of natural hazards (RP) \\
\hline \multirow{5}{*}{$\begin{array}{l}\text { Cultural services } \\
\text { (SC) }\end{array}$} & Spiritual and religious values (VER) \\
\hline & Aesthetic values (VE) \\
\hline & Sense of place (SL) \\
\hline & Recreation and Ecotourism (RE) \\
\hline & Cultural heritage values (VPC) \\
\hline \multicolumn{2}{|c|}{ Existing ecosystem processes } \\
\hline \multirow{4}{*}{$\begin{array}{c}\text { Regulation } \\
\text { Service Climatic } \\
\text { (RC) }\end{array}$} & Regulation of evapotranspiration (RE) \\
\hline & Albedo regulation (RAL) \\
\hline & Production of suspended particles (PPS) \\
\hline & $\begin{array}{c}\text { Carbon sequestration and storage by } \\
\text { plants (SAC) }\end{array}$ \\
\hline
\end{tabular}

Source: Own elaboration based on interviews with experts from the first phase.

Note: ACD: University and academic researchers;

ES: Specialists from public technical organizations of the Peruvian state; REP: Representatives of the communities attached to the study area.

Based on the proposal of Smith et al., [36] 2011, the ecosystemic processes that allow the development of the climate regulation service were identified, the purpose of this process is to obtain a factor with a quantifiable economic value, in this case the sequestration of $\mathrm{CO}_{2}$ eq represents this end [31].

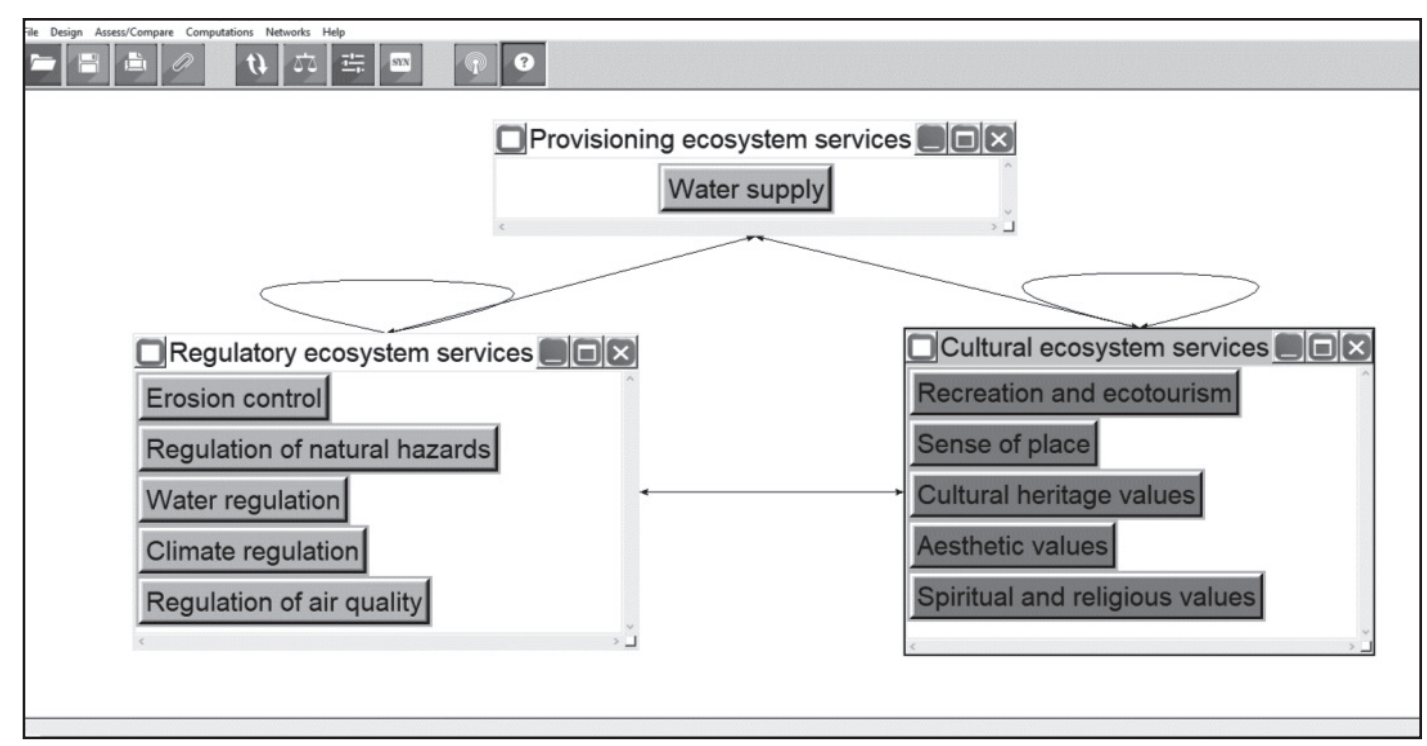

Fig. 2. Interdependencies between ecosystem services. 
Table 3. Prioritization vectors of group 1 of experts.

\begin{tabular}{|c|c|c|c|c|c|c|c|}
\hline \multirow{2}{*}{\multicolumn{2}{|c|}{ Ecosystem services }} & \multicolumn{4}{|c|}{ Experts } & \multirow{3}{*}{$\begin{array}{c}\text { Media Geometric } \\
0.0972\end{array}$} & \multirow{3}{*}{$\begin{array}{c}\text { Standardization } \\
0.1069\end{array}$} \\
\hline & & \multirow{2}{*}{$\begin{array}{c}\text { ACD 1 } \\
0.1141\end{array}$} & \multirow{2}{*}{$\begin{array}{l}\text { ACD 2 } \\
0.1148\end{array}$} & \multirow{2}{*}{$\frac{\text { ACD } 3}{0.1272}$} & \multirow{2}{*}{$\frac{\text { RE } 3}{0.0536}$} & & \\
\hline SA & PA & & & & & & \\
\hline \multirow{5}{*}{ SR } & RCA & 0.0531 & 0.0223 & 0.1689 & 0.1633 & 0.0756 & 0.0831 \\
\hline & $\mathrm{RC}$ & 0.1248 & 0.1459 & 0.2819 & 0.2702 & 0.1930 & 0.2121 \\
\hline & RA & 0.1834 & 0.1252 & 0.0779 & 0.0499 & 0.0972 & 0.1069 \\
\hline & $\mathrm{CE}$ & 0.1889 & 0.2235 & 0.0840 & 0.0886 & 0.1331 & 0.1463 \\
\hline & $\mathrm{RP}$ & 0.2077 & 0.2644 & 0.1336 & 0.1235 & 0.1735 & 0.1908 \\
\hline \multirow{5}{*}{ SC } & VER & 0.0071 & 0.0070 & 0.0058 & 0.0087 & 0.0071 & 0.0078 \\
\hline & VE & 0.0412 & 0.0266 & 0.0264 & 0.0476 & 0.0342 & 0.0376 \\
\hline & SL & 0.0240 & 0.0266 & 0.0286 & 0.0969 & 0.0365 & 0.0401 \\
\hline & $\mathrm{RE}$ & 0.0253 & 0.0266 & 0.0309 & 0.0579 & 0.0331 & 0.0364 \\
\hline & VPC & 0.0305 & 0.0171 & 0.0347 & 0.0398 & 0.0291 & 0.0320 \\
\hline \multicolumn{2}{|c|}{ Total } & 1.0000 & 1.0000 & 1.0000 & 1.0000 & 0.9097 & 1.0000 \\
\hline \multirow{2}{*}{\multicolumn{2}{|c|}{ Ecosystem processes }} & \multicolumn{4}{|c|}{ Experts } & \multirow{2}{*}{ Media Geometric } & \multirow{2}{*}{ Standardization } \\
\hline & & ACD 1 & $\mathrm{ACD} 2$ & ACD 3 & RE 3 & & \\
\hline \multirow{4}{*}{$\mathbf{R C}$} & REV & 0.4874 & 0.1000 & 0.1554 & 0.2789 & 0.2144 & 0.2477 \\
\hline & RAL & 0.1266 & 0.1000 & 0.0630 & 0.1130 & 0.0974 & 0.1126 \\
\hline & PPS & 0.2234 & 0.1000 & 0.0630 & 0.0501 & 0.0916 & 0.1058 \\
\hline & SAC & 0.1625 & 0.7000 & 0.7186 & 0.5581 & 0.4621 & 0.5339 \\
\hline \multicolumn{2}{|c|}{ Total } & 0.0000 & 1.0000 & 1.0000 & 1.0000 & 0.8656 & 1.0000 \\
\hline
\end{tabular}

Source: Own elaboration based on interviews with experts from the third phase.

Table 2 shows the ecosystem goods and services provided by the relict high-Andean forest, as well as the ecosystem processes of the climate regulation service.

In the second phase of interviews, once the ecosystem goods and services had been identified, we proceeded to determine and quantify their influences and interdependencies and, consequently, to determine the prioritization vectors, this process was carried out in the Super Decisions software version 2.8.0.

Tables 3 and 4 show the prioritization vectors for each expert, and Fig. 2 shows the interdependencies between ecosystem goods and services.

The third phase of the study analyzes the prioritization vectors according to the perspectives of the evaluators, attributable to the existence of interests towards the valued asset [15]. With the support of SPSS Statistics 25.0 software, the dendrogram (Fig. 3) and the box and whisker diagram (Fig. 4) were carried out.

It is noted that group 1 is composed mostly of university researchers and academics who show a greater interest in regulating ecosystem services with $74 \%$ of importance, these services are generally not easily perceived by the community and involve a projection especially in conservation issues; on the other hand, group 2 is made up of specialists from public technical agencies of the Peruvian state and

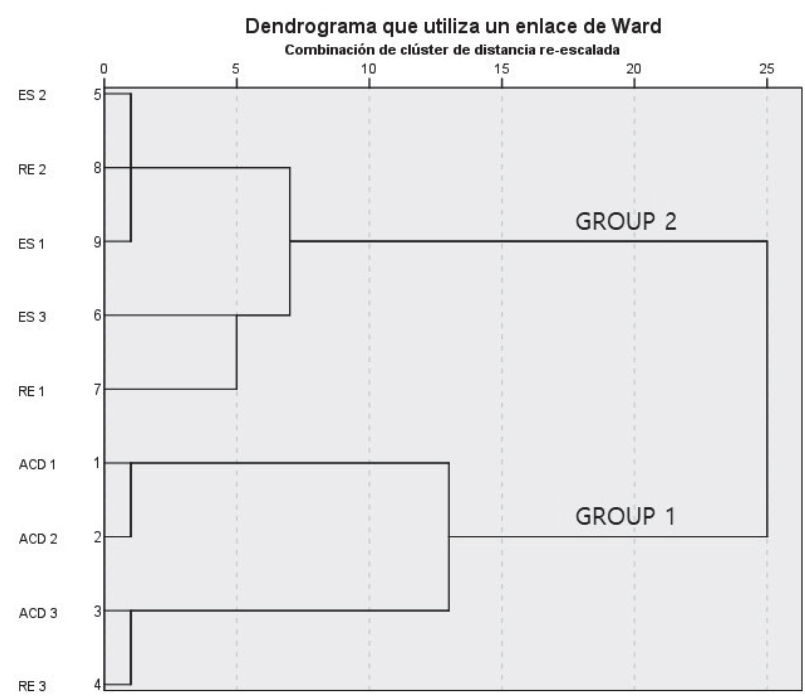

Fig. 3. Dendrogram of the cluster analysis of the prioritization vectors. 
Table 4. Prioritization vectors of group 2 experts.

\begin{tabular}{|c|c|c|c|c|c|c|c|c|}
\hline \multirow{2}{*}{\multicolumn{2}{|c|}{ Ecosystem services }} & \multicolumn{5}{|c|}{ Experts } & \multirow{3}{*}{$\begin{array}{c}\text { Media Geometric } \\
0.2413\end{array}$} & \multirow{3}{*}{$\begin{array}{c}\text { Standardization } \\
0.2597\end{array}$} \\
\hline & & \multirow{2}{*}{$\begin{array}{c}\text { ES 1 } \\
0.1934\end{array}$} & \multirow{2}{*}{$\frac{\text { ES 2 }}{0.1903}$} & \multirow{2}{*}{$\begin{array}{c}\text { ES } 3 \\
0.3670\end{array}$} & \multirow{2}{*}{$\begin{array}{c}\text { RE } 1 \\
0.3092\end{array}$} & \multirow{2}{*}{$\frac{\text { RE } 2}{0.1959}$} & & \\
\hline $\mathbf{S A}$ & PA & & & & & & & \\
\hline \multirow{5}{*}{ SR } & RCA & 0.0205 & 0.0328 & 0.0066 & 0.0246 & 0.0243 & 0.0193 & 0.0207 \\
\hline & $\mathrm{RC}$ & 0.0680 & 0.0705 & 0.0260 & 0.1449 & 0.0990 & 0.0709 & 0.0763 \\
\hline & RA & 0.1097 & 0.0941 & 0.0761 & 0.1602 & 0.0911 & 0.1028 & 0.1106 \\
\hline & $\mathrm{CE}$ & 0.1087 & 0.0955 & 0.1712 & 0.0812 & 0.0868 & 0.1046 & 0.1126 \\
\hline & $\mathrm{RP}$ & 0.0963 & 0.1120 & 0.0366 & 0.0946 & 0.1009 & 0.0823 & 0.0885 \\
\hline \multirow{5}{*}{$\mathrm{SC}$} & VER & 0.0207 & 0.0575 & 0.0109 & 0.0038 & 0.0274 & 0.0168 & 0.0181 \\
\hline & VE & 0.1072 & 0.0880 & 0.0859 & 0.0285 & 0.0842 & 0.0721 & 0.0775 \\
\hline & SL & 0.1030 & 0.0987 & 0.1689 & 0.0801 & 0.0955 & 0.1056 & 0.1137 \\
\hline & $\mathrm{RE}$ & 0.1284 & 0.0899 & 0.0283 & 0.0486 & 0.1216 & 0.0720 & 0.0775 \\
\hline & VPC & 0.0440 & 0.0708 & 0.0226 & 0.0243 & 0.0733 & 0.0417 & 0.0448 \\
\hline \multicolumn{2}{|c|}{ Total } & 1.0000 & 1.0000 & 1.0000 & 1.0000 & 1.0000 & 0.9292 & 1.0000 \\
\hline \multirow{2}{*}{\multicolumn{2}{|c|}{ Ecosystem processes }} & \multicolumn{5}{|c|}{ Experts } & \multirow{2}{*}{ Media Geometric } & \multirow{2}{*}{ Standardization } \\
\hline & & ES 1 & ES 2 & ES 3 & RE 1 & RE 2 & & \\
\hline SA & PA & 0.1934 & 0.1903 & 0.3670 & 0.3092 & 0.1959 & 0.2413 & 0.2597 \\
\hline \multirow{4}{*}{$\mathbf{R C}$} & REV & 0.3310 & 0.3943 & 0.2296 & 0.1062 & 0.1514 & 0.2171 & 0.2450 \\
\hline & RAL & 0.2407 & 0.0956 & 0.0814 & 0.2133 & 0.1514 & 0.1433 & 0.1618 \\
\hline & PPS & 0.1876 & 0.2867 & 0.0814 & 0.0467 & 0.0624 & 0.1049 & 0.1185 \\
\hline & SAC & 0.2407 & 0.2234 & 0.6077 & 0.6339 & 0.6348 & 0.4205 & 0.4747 \\
\hline \multicolumn{2}{|c|}{ Total } & 1.0000 & 1.0000 & 1.0000 & 1.0000 & 1.0000 & 0.8858 & 1.0000 \\
\hline
\end{tabular}

Source: Own elaboration from interviews with Experts from the third phase.

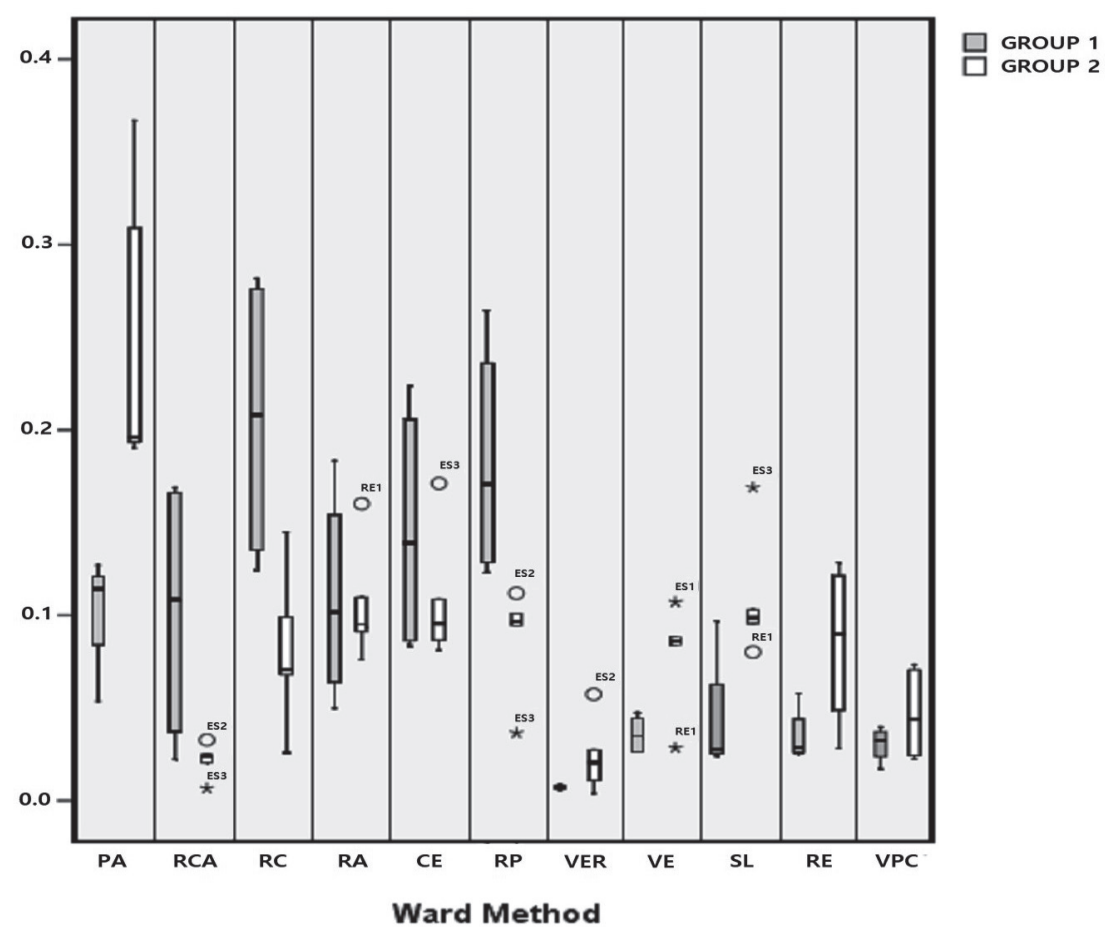

Fig. 4. Box and whisker diagram of the prioritization vectors of Experts on ecosystem services. 
Table 5. Economic value of $\mathrm{CO}_{2}$ equivalent sequestration.

\begin{tabular}{|c|c|c|}
\hline Carbon pool & $\mathbf{C O}_{2}$ eq (t) & Valor (USD) \\
\hline Arboreal & 77167.83 & 553,293 \\
\hline Bush & 8637.49 & 61,931 \\
\hline Herbaceous & 21001.33 & 150,580 \\
\hline Underground & 21569.90 & 154,656 \\
\hline Litter and debris & 19388.33 & 139,014 \\
\hline Floor & 367815.57 & $2,637,238$ \\
\hline Total & 515580.46 & $3,696,712$ \\
\hline
\end{tabular}

Source: Own elaboration.
The fourth phase of the study estimates the economic value of the pivot and of the goods and services offered by the ecosystem. Since there are no supply services with market presence, the ecosystemic process of $\mathrm{CO}_{2}$ eq sequestration was used as a pivot, whose approach is based on the assumption of the loss and degradation of this ecosystem in terms of $\mathrm{CO}_{2}$ emissions that could be released into the atmosphere, thus the social price of carbon in Peru was used [35], obtaining an estimate of USD 3,696,712 for this ecosystem process (Table 5). Next, the economic value of the climate regulation service was estimated at USD 6,923,854 for group 1 of experts and USD 7,787,190 for group 2 of experts (Table 6). Based on the results obtained

Table 6. Economic value of Ecosystem services.

\begin{tabular}{|c|c|c|c|c|c|}
\hline \multirow{2}{*}{\multicolumn{2}{|c|}{ Ecosystem services }} & \multicolumn{2}{|c|}{ Group 1} & \multicolumn{2}{|c|}{ Group 2} \\
\hline & & Media geometric & Value monetary & Media geometric & Value monetary \\
\hline SA & PA & 0.1069 & $3,488,030$ & 0.2597 & $26,511,691$ \\
\hline \multirow{5}{*}{ SR } & $\mathrm{RCA}$ & 0.0831 & $2,714,025$ & 0.0207 & $2,116,364$ \\
\hline & $\mathrm{RC}$ & 0.2121 & $6,923,854$ & 0.0763 & $7,787,190$ \\
\hline & RA & 0.1069 & $3,487,816$ & 0.1106 & $11,292,159$ \\
\hline & $\mathrm{CE}$ & 0.1463 & $4,776,801$ & 0.1126 & $11,492,086$ \\
\hline & $\mathrm{RP}$ & 0.1908 & $6,226,371$ & 0.0885 & $9,040,777$ \\
\hline \multirow{5}{*}{ SC } & VER & 0.0078 & 254,047 & 0.0181 & $1,848,977$ \\
\hline & $\mathrm{VE}$ & 0.0376 & $1,228,486$ & 0.0775 & $7,916,851$ \\
\hline & SL & 0.0401 & $1,309,007$ & 0.1137 & $11,606,897$ \\
\hline & RE & 0.0364 & $1,188,205$ & 0.0775 & $7,907,928$ \\
\hline & VPC & 0.0320 & $1,044,747$ & 0.0448 & $4,577,132$ \\
\hline \multicolumn{2}{|c|}{ Total } & 1.0000 & $32,641,387$ & 1.0000 & $102,098,052$ \\
\hline \multirow{2}{*}{\multicolumn{2}{|c|}{ Ecosystem processes }} & \multicolumn{2}{|c|}{ Group 1} & \multicolumn{2}{|c|}{ Group 2} \\
\hline & & $\begin{array}{c}\text { Media geometric } \\
\text { normalized }\end{array}$ & $\begin{array}{c}\text { Value monetary } \\
\text { (USD) }\end{array}$ & $\begin{array}{c}\text { Media geometric } \\
\text { normalized }\end{array}$ & $\begin{array}{c}\text { Value monetary } \\
\text { (USD) }\end{array}$ \\
\hline \multirow{4}{*}{ RC } & $\mathrm{RE}$ & 0.2477 & $1,714,971$ & 0.2450 & $1,908,140$ \\
\hline & RAL & 0.1126 & 779,323 & 0.1618 & $1,259,780$ \\
\hline & PPS & 0.1058 & 732,848 & 0.1185 & 922,558 \\
\hline & SAC & 0.5339 & $3,696,712$ & 0.4747 & $3,696,712$ \\
\hline \multicolumn{2}{|c|}{ Total } & 1.0000 & $6,923,854$ & 1.0000 & $7,787,190$ \\
\hline
\end{tabular}

Source: Own elaboration

representatives of the communities annexed to the study area, whose analysis showed a greater interest in provisioning and cultural services with $26 \%$ and $33 \%$ of importance respectively, this allows us to interpret the perception of usefulness that this group has of the resources provided directly by the study area. above, the economic value of the ecosystem services identified was assessed, projecting the economic value of the climate regulation service on the prioritization vectors of each group (Table 6), obtaining a range that goes from USD $32,641,387$ to USD 102,098,052 respectively. 


\section{Conclusions}

This paper has described a variation in the application of the AMUVAM method, which includes the development of the ANP model as the one that allowed us to analyze the various interrelationships that exist within the relict high-Andean ecosystem, on the other hand, the use of a pivot value corresponding to the ecosystemic process of a regulating service and not to a provisioning service as is traditionally done [31], this variation allows amplifying the application of the method in new studies that present ecosystems with similar conditions.

The different interests of the evaluators have allowed establishing an economic value range from USD $32,641,387$ to USD $102,098,052$ on the development of the goods and services offered by the ecosystem to the society involved. We understand that establishing a range allows avoiding questions regarding the accuracy of the valuation, in addition to knowing a coherent monetary distribution on the importance of the ecosystem studied [15]

The results of the research constitute an influential potential for decision making, in order to design planning strategies for the conservation, use and sustainable benefit of the relict high-Andean ecosystem in the province of Arequipa.

\section{Acknowledgements}

This study was financially supported by the Universidad Nacional de San Agustín de Arequipa through contract $\mathrm{N}^{\mathrm{a}}$ TP-05-2019-UNSA.

Also thank the following people: Joyce Valdivia, Carmelo Talavera, Benigno Sanz, Juan Carlos Barahona, Ulrich Zanabria, José Villasante, Juan Pinto, Alejandro Delgado, John Machaca, Yasmely Sarcca, José Muñoz, Flor Menor and Giovana Zapana who contributed to the development from work.

\section{Conflict of Interest}

The authors declare no conflict of interest.

\section{References}

1. CARO-CARO C., TORRES-MORA M. Ecosystem services as support for the management of socio-ecological systems: application in agro-ecosystems. Orinoquia, 19 (2), 237, 2015.

2. MILLENNIUM ECOSYSTEM ASSESSMENT Ecosystems and human well-being: a report on the conceptual framework working group of the Millennium Ecosystem Assessment. Ecosystems Washington, DC, 2003.

3. MILLENNIUM ECOSYSTEM ASSESSMENT Ecosystems and Human Well-being: Synthesis. Washington, DC: Island Press, 2005.
4. MILCU A.I., HANSPACH J., ABSON D., FISCHER J. Cultural Ecosystem Services: A Literature Review and Prospects for Future Research. Ecology and Society, art 44, 18 (3), 2013.

5. CHAO S. Forest peoples: Numbers across the world. Forest Peoples Programme (Moreton-in.). United Kingdom, 2012.

6. FAO Global Forest Resources Assessment 2020 - Key Findings. Food and Agriculture Organization of the United Nations. Rome, 2020.

7. FAO The State of the World's Forests 2016 Forests and agriculture: challenges and opportunities in relation to land use. Rome, 2016.

8. MINAM Forest conservation in Peru (2011-2016), Conserving forests in a context of climate change as a contribution to green growth. Lima, 2016.

9. LA TORRE-CUADROS M. State of the scientific art on the management of Andean forests in Peru. National Forest and Wildlife Service, Andean Forests Program of the Swiss Agency for Development and Cooperation - COSUDE, HELVETAS Swiss Intercooperation, CONDESAN. Lima, 2016.

10. MINAM National Map of Peruvian Ecosystems, descriptive memory. Ministry of the Environment of Peru. Lima, 2018.

11. CUYCKENS G.A.E., RENISON D. Ecology and conservation of the Polylepis mountain forests: An introduction to the special issue. Southern Ecology, 28 (1), 157, 2018.

12. SYLVESTER S.P., HEITKAMP F., SYLVESTER M.D.P.V., JUNGKUNST H.F., SIPMAN H.J.M., TOIVONEN J.M., GONZALES C.A., OSPINA J C., KESSLER M. Relict high-Andean ecosystems challenge our concepts of naturalness and human impact. Scientific Reports, 7 (1), 1, 2017.

13. MINAM Guide to the Economic Valuation of Natural Heritage. General Direction of Evaluation, Valuation and Financing of the Natural Heritage. Lima, 2016.

14. LAMBERT A. Economic valuation of wetlands - an important component of wetland management strategies at the river basin level. Ramsar Convention on Wetlands, 11, 2003.

15. AZQUETA D. Economic valuation of environmental quality. McGraw Hil. Madrid, 1994.

16. LATERRA P., JOBBÁGY E.G., PARUELO J.M. Valuation of ecosystem services: concepts, tools and applications for land use planning. INTA. Buenos Aires, 2011.

17. GÓMEZ-AGUAYO A.M., ESTRUCH-GUITART V. Economic valuation of marine ecosystem services: A case study of La Safor, Gulf of Valencia, Spain. Ecosystems, 28 (2), 100, 2019.

18. LEUNG L., CAO D. On the efficacy of modeling multi-attribute decision problems using AHP and Sinarchy. European Journal of Operational Research, 132, 39, 2001.

19. CARDELLS F. Strategic planning of forest ecosystems: an application to the Valencian Community. Polytechnic University of Madrid. 1995.

20. MINAM National map of plant coverage: descriptive report. Ministry of the Environment, General Directorate of Evaluation, Valuation and Financing of Natural Heritage. Lima, 2015.

21. CUNAZZA PALIURI C., GRIMBERG PARDO M., DE LA MAZA MUSALEM M. CONAF In the state's protected wilderness areas. Conserving threatened flora and fauna. Santiago, 2013. 
22. SIRANP PRONANP Proposal for the creation of the reserved zone of the queñua forest of the Pichu Pichu, The forests, drainage basin. Retrieved. Arequipa, 2012.

23. SAATY T. Fundamentals of the Analytic Network Process-dependence and Feedback in Decision-making with a Single Network. Journal of Systems Science and Systems Engineering, 13 (2), 129, 2004.

24. AZNAR BELLVER J., GUIJARRO MARTINEZ F. New Methods of Rating Multicriteria Models. Universita Politècnica. Valencia, 2013.

25. POTSCHIN, M. B., HAINES-YOUNG, R. H. Ecosystem services: Exploring a geographical perspective. Progress in Physical Geography, 35 (5), 575, 2011.

26. HAINES-YOUNG R., POTSCHIN M. Common International Classification of Ecosystem Services (CICES) V5.1 and Guidance on the Application of the Revised Structure. 2018.

27. UNITED NATIONS. System of environmental-economic accounting 2012: Experimental Ecosystem Accounting. United Nations, European Union, Food and Agriculture Organization, Organization for Economic Co-operation and Development, New York, 2014.

28. AZIZ T., VAN CAPPELLEN P. Comparative valuation of potential and realized ecosystem services in Southern Ontario, Canada. Environmental Science and Policy, 100, 105, 2019.

29. KEESING F., HOLT R.D., OSTFELD R.S. Effects of species diversity on disease risk. Ecology Letters, 9 (4), 485, 2006.
30. VALLS CIVERA A., ESTRUCH GUITART V. Economic valuation of the ecosystem services associated with the Turia Natural Park (Valencia). Universidad Politécnica de Valencia, 41, 2018.

31. AZNAR BELLVER J., ESTRUCH GUITART A.V. Valuation of Environmental Assets, Theories and Cases. Polytechnic University of Valencia, 2015.

32. SARCCA HUISA Y.R. Economic valuation of the ecosystem service of carbon sequestration and storage in the Polylepis from Pichu Pichu Forest, Arequipa - 2016. Universidad Nacional de San Agustín de Arequipa, 2017.

33. PICARD NICOLAS, SAINT-ANDRÉ LAURENT, HENRY M. Manual of construction of allometric equations to estimate the volume and biomass of trees. The United Nations for Food and Agriculture and the Center for International Cooperation in Agronomic Research for Development. Rome, 2012.

34. CAIRNS M., BROWN S., HELMER E., BAUMGARDNER G. Root biomass allocation in the world's upland forests. Oecologia, 111, 1, 1997.

35. UNIVERSITY OF THE PACIFIC RESEARCH CENTER. Estimation of the social price of carbon for the social evaluation of projects in Peru, 2016.

36. SMITH P., ASHMORE M., BLACK H., BURGESS P., EVANS C., HAILS R., SQUIRE G. Regulating Services. In The UK National Ecosystem Assessment Technical Report. UK NEA Publications. Cambridge, 2011. 